\title{
Monositosis dan Limfositosis Merupakan Faktor Risiko Demam Berdarah Dengue pada Anak
}

\author{
Dana Nur Prihadi, Tetty Yuniati, Azhali Manggus S. \\ Bagian Ilmu Kesehatan Anak \\ Fakultas Kedokteran Universitas Padjadjaran \\ Rumah Sakit Hasan Sadikin, Bandung
}

\begin{abstract}
Abstrak
Infeksi dengue dengan spektrum klinisnya yang luas masih merupakan masalah kesehatan di Indonesia. Respons imun berlebihan pada demam berdarah dengue (DBD) yang mengakibatkan kebocoran plasma terjadi karena produksi sitokin berlebihan oleh monosit serta limfosit yang meningkat jumlah dan aktivitasnya. Penelitian ini bertujuan untuk mengetahui apakah monositosis dan limfositosis merupakan faktor risiko DBD pada anak. Rancangan penelitian ini adalah kasus kontrol dengan subjek anak usia $\leq 14$ tahun yang memenuhi kriteria klinis demam dengue (DD) dan DBD menurut WHO (1997) disertai bukti infeksi dengue secara serologis. Dilakukan pengambilan sampel darah kapiler pada saat kedatangan atau penegakan diagnosis. Analisis statistik dilakukan dengan uji chi kuadrat dan Mann-Whitney untuk mengetahui karakteristik umum, perbedaan jumlah monosit dan limfosit pada DD dan DBD, serta analisis regresi logistik ganda untuk mengetahui hubungan monositosis dan limfositosis dengan kejadian DBD. Seluruh perhitungan statistik dikerjakan dengan piranti lunak SPSS versi 17.0 for Windows. Didapatkan subjek DD dan DBD masing-masing 50 anak. Rata-rata jumlah monosit pada pasien DD dan DBD adalah $95,16 / \mathrm{mm}^{3}$ dan $215,87 / \mathrm{mm}^{3}$, sedangkan rata-rata jumlah limfosit pada pasien DD dan DBD adalah $1.113,63 / \mathrm{mm}^{3}$ dan $2.830,32 / \mathrm{mm}^{3} ; \mathrm{p}<0,001$. Titik potong jumlah monosit pada DBD yaitu $>96 / \mathrm{mm}^{3}$ dan titik potong jumlah limfosit pada DBD yaitu $>1.472 / \mathrm{mm}^{3}$. Odds ratio (OR) monositosis (interval kepercayaan 95\%) yaitu 6,55; $\mathrm{p}=0,011$ dan OR limfositosis (interval kepercayaan 95\%) yaitu 43,76; $<<0,001$. Dengan adanya monositosis pada infeksi dengue akan terjadi risiko DBD sebanyak 6,55 kali dan dengan adanya limfositosis akan terjadi risiko DBD sebanyak 43,76 kali. Disimpulkan bahwa monositosis dan limfositosis merupakan faktor risiko DBD pada anak. [MKB. 2009;41(4):201-6].
\end{abstract}

Kata kunci: Monositosis, limfositosis, demam berdarah dengue

\section{Monocytosis and Lymphocytosis are Risk Factors of Dengue Hemorrhagic Fever in Children}

\begin{abstract}
Dengue infection with its broad clinical spectrum remains a health problem in Indonesia. An aberrant immune response in plasma leakage of dengue hemorrhagic fever (DHF) caused by increases of monocytes and lymphocytes. The aim of this study was to investigate that monocytosis and lymphocytosis were risk factor of DHF in children. A case control study was conducted at Child Health Department Hasan Sadikin General Hospital, Bandung, from April to June, 2009. Children aged $\leq 14$ years who fulfilled the clinical criteria for dengue fever (DF) and dengue hemorrhagic fever (DHF), according to WHO (1997) confirmed with serologic test. Monocytes and lymphocytes count were measured on admission. Data were analyzed using chi square test, Mann-Whitney test, and multiple logistic regression. The best cut-off point was determined using receiver operator characteristic (ROC) curve. All
\end{abstract}

Korespondensi: dr. Dana Nur Prihadi,Sp.A, Bagian Ilmu Kesehatan Anak, Fakultas Kedokteran Universitas Padjadjaran, Rumah Sakit Hasan Sadikin, Jl. Pasteur No. 38 Bandung 40163, Telp. (022) 2035957, HP. 08122019913 ,

Email: danoelhadi@yahoo.co.id 
statistical computations were perfomed using SPSS 17.0 for Windows software. There were 50 DF and 50 DHF. The mean level of monocytes for DF and DHF patients were $95.16 / \mathrm{mm}^{3}$ and $215.87 / \mathrm{mm}^{3} ; \mathrm{p}<0.001$. The mean level of lymphocytes for DF and DHF patients were $1,113.63 / \mathrm{mm}^{3}$ and $2,830.32 / \mathrm{mm}^{3} ; \mathrm{p}<0.001$. Cut-off point of monocytes was $>96 / \mathrm{mm}^{3}$ and lymphocytes was $>1,472 / \mathrm{mm}^{3}$. Odds ratio (OR) of monocytosis (confidence interval $95 \%$ ) was $6.55 ; p=0.011$ and OR of lymphocitosis (confidence interval $95 \%$ ) was $43.76 ; p<0,001$. If monocytosis was present, risk of DHF was 6.55 and lymphocytosis was present, risk of DHF was 43.76. It is concluded that monocytosis and lymphocytosis are risk factors of DHF in children. [MKB. 2009;41(4):201-6].

Key words: Monocytosis, lymphocytosis, dengue hemorrhagic fever

\section{Pendahuluan}

Penyakit infeksi dengue sampai saat ini masih merupakan masalah kesehatan yang sangat serius di daerah tropis sedunia. Selama 40 tahun terakhir, insidensi demam dengue (DD) dan demam berdarah dengue (DBD) terus meningkat. Diperkirakan terjadi 50 juta kasus infeksi virus dengue dan 500.000 kasus DBD dan sindrom syok dengue (SSD) yang memerlukan perawatan rumah sakit setiap tahunnya dengan mortalitas sekitar $1-5 \%$ atau 24.000 jiwa, dan mayoritas penderita adalah anak di bawah usia 15 tahun. ${ }^{1,2}$ Berdasarkan data profil kesehatan Indonesia tahun 2007 terdapat 158.115 kasus DBD dengan case fatality rate (CFR) sebesar $1,01 \%{ }^{3}$

Infeksi virus dengue memiliki spektrum klinis yang sangat luas, yaitu dapat asimtomatis maupun bermanifestasi klinis sebagai demam yang tidak spesifik (undifferentiated fever), demam dengue (DD), atau demam berdarah dengue (DBD). Kebocoran plasma dikarenakan oleh peningkatan permeabilitas vaskular terjadi pada DBD yang ditandai peningkatan hematokrit atau penurunan hematokrit setelah tindakan penggantian volume sama atau lebih besar dari $20 \%$ di atas rata-rata usia, jenis kelamin, dan populasi, efusi pleural, asites, dan hipoproteinemia. Hal ini tidak terjadi pada DD. ${ }^{1,4}$

Mekanisme yang dapat menunjang terjadinya DBD adalah peningkatan replikasi virus dalam sel mononukleus yaitu pada monosit atau makrofag sebagai sel target utama dan berperan sebagai antigen presenting cell (APC) yang akan mengaktivasi sel limfosit, sehingga menghasilkan antibodi netralisasi, hemaglutinasi, dan fiksasi komplemen. $^{5}$

Respons imun selular dan humoral berupa peningkatan jumlah serta aktivitas monosit dan limfosit, sehingga produksi sitokin berlebih dapat menimbulkan perembesan plasma dan jumlah serta aktivitas sel limfosit mempunyai peran yang sangat penting dalam imunopatogenesis infeksi virus dengue. ${ }^{5,6}$

Penelitian tentang monosit dan limfosit pernah dilakukan oleh Lai et al., Limkittikul et al., ${ }^{8}$ Jampangagern et al., ${ }^{9}$ Liu et al., ${ }^{10}$ dan Villegas et al. ${ }^{11}$ Sedangkan penelitian limfosit pada anak yaitu Green et al., ${ }^{12}$ Carlos et al., ${ }^{13}$ Wells et al., ${ }^{14}$ Ardianto dkk., ${ }^{15}$ dan Myint et al. ${ }^{16}$

Penelitian ini bertujuan untuk mengetahui apakah monositosis dan limfositosis merupakan faktor risiko DBD pada anak dapat digunakan untuk membantu penilaian dan pemantauan, serta penanganan penderita demam berdarah dengue supaya lebih baik dan cepat, terutama di daerah yang terbatas fasilitas pemeriksaan penunjangnya, sehingga diharapkan dapat menurunkan angka kematian akibat infeksi dengue.

\section{Metode}

Dilakukan penelitian kasus kontrol pada bulan April-Juni 2009. Pemilihan subjek dilakukan pada anak yang menderita DD dan DBD yang dirawat di Bagian/SMF Ilmu Kesehatan Anak RS Hasan Sadikin setelah mendapat persetujuan dari orangtua. Sebagai kriteria inklusi adalah penderita anak usia $\leq 14$ tahun; memenuhi kriteria klinis DD dan DBD menurut WHO (1997) disertai bukti infeksi dengue secara serologis. Kriteria eksklusi subjek menderita penyakit infeksi lain misalnya morbili dan demam tifoid, SSD, penyakit dengan gangguan sistem imun, kelainan darah atau keganasan atau mendapatkan obat-obatan imunosupresan seperti preparat kortikosteroid atau sitostatika dalam dua minggu terakhir.

Dengan taraf kemaknaan $95 \%$ dan power test $80 \%$ didapatkan besar sampel minimal untuk masing-masing kelompok adalah 43, sehingga jumlah sampel adalah 100. Pada subjek dilakukan 
anamnesis, pemeriksaan fisis, dan pengambilan darah vena untuk pemeriksaan jumlah monosit dan limfosit yang dilakukan saat kedatangan di rumah sakit. Pada hari panas kelima diperiksakan serologis IgM dan IgG antidengue. Kriteria klinis DD sesuai dengan kriteria klinis DBD menurut WHO tanpa disertai adanya hemokonsentrasi/ peningkatan hematokrit $\geq 20 \%$ atau bukti kebocoran plasma. Kriteria DBD adalah ditemukannya 2 kriteria klinis ditambah 1 kriteria laboratorium (sedikitnya terdapat peningkatan hematokrit) berupa: panas badan atau riwayat panas badan mendadak selama 2-7 hari; adanya tendensi perdarahan; trombositopenia $\left(\leq 100.000 / \mathrm{mm}^{3}\right)$; dan terjadi kebocoran plasma. Adanya infeksi dengue terbukti secara serologis bila hasil IgM dan atau IgG antidengue positif. ${ }^{1,4}$
Untuk mengetahui adanya perbedaan karakteristik umum, jumlah monosit dan limfosit pada kedua kelompok digunakan uji chi kuadrat dan Mann-Whitney. Untuk mengetahui jumlah monosit dan limfosit DBD digunakan kurva receiver operating characteristics (ROC). Analisis regresi ganda untuk mengetahui hubungan monositosis dan limfositosis dengan kejadian DBD. Untuk seluruh perhitungan statistik dikerjakan dengan piranti lunak SPSS versi 17.0 for Windows tahun 2007, SPSS Inc, Chicago-Illinois, USA.

\section{Hasil}

Selama kurun waktu penelitian, didapatkan 133 anak yang memenuhi kriteria klinis DD, DBD,

Tabel 1 Karakteristik Umum Subjek Penelitian

\begin{tabular}{lccc}
\hline Karakteristik & DD & DBD & Nilai $\boldsymbol{p}$ \\
\hline Jenis kelamin & $\mathbf{5 0}(\mathbf{\%})$ & $\mathbf{5 0}(\mathbf{\%})$ & $0,161^{*}$ \\
Laki-laki & $22(44)$ & $29(58)$ & \\
Perempuan & $28(56)$ & $21(42)$ & \\
Usia (tahun) & & $7,18(3,85)$ & $0,138^{* *}$ \\
Rerata (SB) & $8,34(3,62)$ & 6,75 & \\
Median & 9 & $0,33-13,3$ & $0,167^{*}$ \\
Rentang & $0,42-13,58$ & $6(12)$ & \\
Status gizi & $11(22)$ & $42(84)$ & \\
Kurang & $39(78)$ & $2(4)$ & $0,841^{* *}$ \\
Baik & $0(0)$ & & \\
Lebih & $4,67(0,94)$ & $4,74(0,99)$ & \\
Hari sakit saat datang & 5 & 5 & $0,074^{*}$ \\
Rata-rata (SB) & $2-6$ & $3-7$ & \\
Median & $13(26)$ & $6(12)$ & \\
Rentang & $37(74)$ & $44(88)$ & \\
Status infeksi & Primer & &
\end{tabular}

Tabel 2 Jumlah Monosit dan Limfosit pada DD dan DBD

\begin{tabular}{lccc}
\hline Jumlah $\left(/ \mathbf{m m}^{\mathbf{3}}\right)$ & $\begin{array}{c}\text { DD } \\
(\mathbf{n}=\mathbf{5 0})\end{array}$ & $\begin{array}{c}\text { DBD } \\
(\mathbf{n = 5 0})\end{array}$ & Kemaknaan \\
\hline Monosit & $95,16(82,89)$ & $215,87(154)$ & $\mathrm{Z}_{\mathrm{M}-\mathrm{W}}=4,867$ \\
Rata-rata $(\mathrm{SB})$ & 78 & 177 & $p<001^{*}$ \\
Median & $0-320$ & $0-650$ & \\
Rentang & & & \\
Limfosit & $1.113,63(371,209)$ & $2.830,32(1.643,23)$ & $\mathrm{Z}_{\mathrm{M}-\mathrm{W}}=7,225$ \\
Rata-rata (SB) & 1.127 & 2.340 & $p<001^{*}$ \\
Median & $170-1.802$ & $660-8.100$ & \\
Rentang & &
\end{tabular}


Tabel 2 Jumlah Monosit dan Limfosit pada DD dan DBD

\begin{tabular}{|c|c|c|c|}
\hline Jumlah $\left(/ \mathrm{mm}^{3}\right)$ & $\begin{array}{c}\text { DD } \\
(n=50)\end{array}$ & $\begin{array}{c}\text { DBD } \\
(n=50)\end{array}$ & Kemaknaan \\
\hline $\begin{array}{l}\text { Monosit } \\
\text { Rata-rata (SB) } \\
\text { Median } \\
\text { Rentang }\end{array}$ & $\begin{array}{c}95,16(82,89) \\
78 \\
0-320\end{array}$ & $\begin{array}{c}215,87(154) \\
177 \\
0-650\end{array}$ & $\begin{array}{c}\mathrm{Z}_{\mathrm{M}-\mathrm{W}}=4,867 \\
p<0,001^{*}\end{array}$ \\
\hline $\begin{array}{l}\text { Limfosit } \\
\text { Rata-rata (SB) } \\
\text { Median } \\
\text { Rentang }\end{array}$ & $\begin{array}{c}1.113,63(371,209) \\
1.127 \\
170-1.802\end{array}$ & $\begin{array}{c}2.830,32(1.643,23) \\
2.340 \\
660-8.100\end{array}$ & $\begin{array}{c}\mathrm{Z}_{\mathrm{M}-\mathrm{W}}=7,225 \\
p<0,001^{*}\end{array}$ \\
\hline
\end{tabular}

Keterangan: * = Uji Mann-Whitney U, SB = simpang baku

Tabel 3 Validitas Hasil Penelitian Monosit dan Limfosit untuk Memprediksi DBD

\begin{tabular}{|c|c|c|c|c|c|}
\hline $\begin{array}{c}\text { Titik Potong } \\
\left(/ \mathrm{mm}^{3}\right)\end{array}$ & $\begin{array}{c}\text { DBD } \\
(n=50)\end{array}$ & $\begin{array}{c}\text { DD } \\
(n=50)\end{array}$ & $\begin{array}{c}\text { Sensitivitas } \\
(\%)\end{array}$ & $\begin{array}{c}\text { Spesifisitas } \\
(\%)\end{array}$ & $\begin{array}{l}\text { Akurasi } \\
(\%)\end{array}$ \\
\hline Monosit & & & 86 & 60 & 73 \\
\hline$>96$ & 43 & 20 & & & \\
\hline$\leq 96$ & 7 & 30 & & & \\
\hline Limfosit & & & 90 & 86 & 88 \\
\hline$>1.472$ & 45 & 7 & & & \\
\hline$\leq 1.472$ & 5 & 43 & & & \\
\hline
\end{tabular}

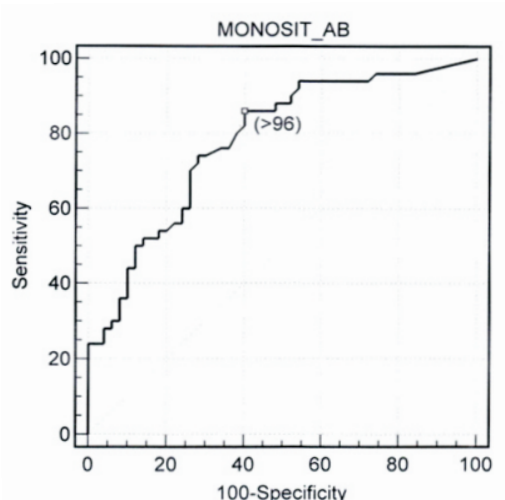

Gambar 1 Kurva ROC Monosit

dan SSD. Sebanyak 100 anak memenuhi kriteria inklusi penelitian terdiri dari 50 anak menerita DD sebagai kontrol dan 50 anak menderita DBD sebagai kelompok kasus, sedangkan 33 anak lainnya tidak dimasukkan kedalam penelitian dengan alasan sebagai berikut: 27 anak menderita SSD, empat anak tidak terbukti menderita infeksi dengue secara serologis, dan dua anak disertai (koinfeksi) dengan penyakit demam tifoid.

Dari 100 anak yang masuk kriteria penelitian didapatkan proporsi jenis kelamin yang hampir sama (49 anak perempuan dan 51 anak laki-laki), dengan rata-rata usia 8,37 tahun pada DD dan 7,18 tahun pada DBD. Terdapat 39 anak dengan status

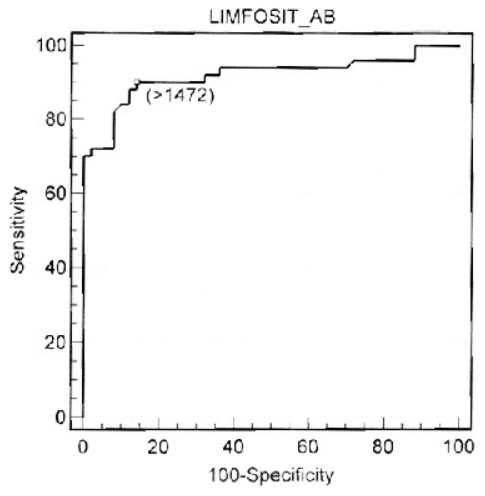

Gambar 2 Kurva ROC Limfosit

gizi baik pada DD dan 42 anak pada DBD. Ratarata hari sakit saat datang ke rumah sakit yaitu 4,67 penderita DD, sedangkan pada DBD yaitu 4,74 hari. Pada kelompok DD didapatkan 13 (26\%) kasus dengan status infeksi primer dan 37 (74\%) kasus dengan status infeksi sekunder, sedangkan pada kelompok DBD didapatkan enam $(12 \%)$ kasus dengan status infeksi primer dan 44 (88\%) kasus dengan status infeksi sekunder, seperti yang terlihat pada Tabel 1.

Jenis kelamin $(p=0,161)$, usia $(p=0,138)$, status gizi $(\mathrm{p}=0,167)$, hari sakit pada saat datang $(p=0,841)$, dan status infeksi $(p=0,074)$ tidak terdapat perbedaan yang bermakna secara statistik 
Tabel 4 Hubungan Monositosis dan Limfositosis Secara Simultan dengan Kejadian DBD Berdasarkan Analisis Regresi Logistik Ganda

\begin{tabular}{ccccc}
\hline Variabel & Keofisien B & SE B & Nilai $\boldsymbol{p}$ & OR (95\% CI) \\
\hline Limfositosis & 3,779 & 0,688 & $<0,001$ & $43,76(11,37-168,41)$ \\
Monositosis & 1,879 & 0,739 & 0,011 & $6,55 \quad(1,55-27,70)$ \\
Konstanta & 3,685 & 0,825 & & \\
\hline Keterangan: Akurasi model $=88 \%, \mathrm{SE}=$ standart error &
\end{tabular}

pada kelompok DD dan DBD.

Untuk mengetahui apakah terdapat perbedaan jumlah monosit dan limfosit pada kelompok DD dan DBD digunakan analisis uji Mann-Whitney, didapatkan perbedaan yang bermakna, yaitu $\mathrm{p}<0,001$ (Tabel 2).

Dengan kurva ROC didapatkan titik potong jumlah monosit $>96 / \mathrm{mm}^{3}$ dan jumlah limfosit $>1.472 / \mathrm{mm}^{3}$.

Dengan menggunakan titik potong didapatkan jumlah monosit $>96 / \mathrm{mm}^{3}$ dan jumlah limfosit $>1.472 / \mathrm{mm}^{3}$. Monositosis pada DBD (43 anak) dan DD (17 anak) dengan sensitivitas $86 \%$, dan spesifitas $60 \%$, serta akurasi $73 \%$. Limfositosis pada DBD (45 anak) dan DD (lima anak) dengan sensitivitas $90 \%$, spesifisitas $86 \%$, dan akurasi $88 \%$, dapat dilihat pada Tabel 3 .

Pada Tabel 4 terlihat perbedaan bermakna limfositosis $(p<0,001)$ dan monositosis $(p=0,011)$ dengan kejadian DBD dan DD.

\section{Pembahasan}

Spektrum klinis infeksi dengue bervariasi mulai dari gejala mirip influenza yang dikenal sebagai DD sampai manifestasi berat dan fatal ditandai perdarahan dan syok yang disebut DBD dan SSD. Pada penelitian ini dari 100 anak yang masuk kriteria inklusi subjek penelitian dikelompokkan menjadi: DD 50 anak (50\%) dan DBD 50 anak $(50 \%)$.

Dari data karakteristik umum secara keseluruhan tidak terdapat perbedaan statistik yang bermakna $(p>0,05)$ antara variabel jenis kelamin, usia, status gizi, hari sakit saat datang, serta status infeksi pada DD dan DBD, hasil ini sesuai dengan penelitian yang dilakukan oleh Green et al., ${ }^{12}$ Carlos et al. ${ }^{13}$ dan Juffrie et al. ${ }^{17}$ Pada kelompok DBD didapatkan rata-rata jumlah monosit dan limfosit lebih tinggi daripada kelompok DD; $\mathrm{p}<0,001$, hasil ini sesuai dengan penelitian yang dilakukan oleh Lai et al., ${ }^{7}$ Limkittikul K. et al.,
Jampangern et al. ${ }^{9}$ dan Liu et al..$^{10}$

Dengan menggunakan titik potong yang didapatkan dari kurva ROC yaitu jumlah monosit $>96 / \mathrm{mm}^{3}$ mempunyai sensitivitas $86 \%$, spesifisitas $60 \%$, dan akurasi $73 \%$, sedangkan jumlah limfosit $>1.472 / \mathrm{mm}^{3}$ mempunyai sensitivitas $90 \%$, spesifisitas $86 \%$, dan akurasi $88 \%$. Setelah dilakukan analisis regresi ganda didapatkan bahwa monositosis dan limfositosis merupakan faktor risiko DBD dengan OR limfositosis (interval kepercayaan 95\%) $=43,76(11,37-168,41)$; $\mathrm{p}<0,001$ dan OR monositosis (interval kepercayaan $95 \%)=6,55(1,55-27,70) ; p=0,011$. Infeksi dengue dengan limfositosis berpeluang 43,76 kali untuk terjadinya DBD dibandingkan dengan infeksi dengue tanpa adanya limfositosis dan pada infeksi dengue dengan monositosis berpeluang 6,55 kali untuk terjadinya DBD dibandingkan dengan infeksi dengue tanpa adanya monositosis. Hasil ini sesuai dengan penelitian yang dilakukan oleh Liu et al., ${ }^{10}$ Villegas et al., ${ }^{11}$ Carlos et al., Wells et al. ${ }^{14}$ Ardianto dkk., ${ }^{15}$ dan Myint et al. ${ }^{16}$

Kesimpulan penelitian ini adalah monositosis dan limfositosis merupakan faktor risiko demam berdarah dengue. Bagi para klinisi pemeriksaan jumlah monosit dan limfosit pada anak yang mengalami infeksi dengue sebaiknya dilakukan pada saat penderita datang dan dapat digunakan untuk membantu penilaian, pemantauan, dan penanganan penderita demam berdarah dengue supaya lebih baik dan cepat, terutama di daerah yang terbatas fasilitas pemeriksaan penunjangnya.

\section{Daftar Pustaka}

1. WHO. Dengue haemorrhagic fever. Diagnosis, treatment, prevention and control. Edisi ke-2. Geneva: WHO; 1997.

2. Sapir GD, Schimmer B. Dengue fever: new paradigms for a changing epidemiology. Emerg Themes Epidemiol. 2005;2:1-10.

3. Departemen Kesehatan RI. Profil kesehatan Indonesia 2007. Jakarta: Depkes RI; 2008. 
4. WHO. Dengue, dengue haemorrhagic fever and dengue shock syndrome in the context of integrated management of childhood illness. Geneva: WHO; 2005.

5. Lei HY, Huang KJ, Lin YS, Yeh TM, Liu HS, Liu CC. Immunopathogenesis of dengue hemorrhagic fever. Am J Infect Dis. 2008;4:1-9.

6. Guglani L, Kabra SK. T cell immunopathogenesis of dengue virus infection. Dengue Bull. 2005; 29:58-69.

7. Lai PC, Lee SS, Kao CH, Chen YS, Huang CK, Lin WR, et al. Characteristics of a dengue hemorrhagic fever outbreak in 2001 in Kaohsiung. J Microbiol Immunol Infect. 2004;37:266-70.

8. Limkittikul K, Yingsakmongkon S, Jittmittraphap A, Chuananon S, Kongphrai Y, Kowasupathr S, et al. Clinical differences among PCR-proven dengue serotype infections. Southeast Asian J Trop Med Public Health. 2005;36:1432-8.

9. Jampangern $\mathrm{W}$, Vongthoung $\mathrm{K}$, Jittmittraphap A, Worapongpaiboon S, Limkittikul K, Chuansumrit A, et al. Characterization of atypical lymphocytes and immunophenotypes of lymphocytes in patients with dengue virus infection. Asian Pac J Allergy Immunol. 2007;25:27-36

10. Liu JW, KhorvBS, Lee CH, Lee IK, Chen RF, Yang KD. Dengue haemorrhagic fever in Taiwan. Dengue Bull. 2003;27:19-24.

11. Villegas E, Villegas N, Morales AJ. Ocurrence of neutrophil left shift in dengue haemorrhagic fever. Rev Soc Med Quir Hosp Emerg Perez de Leon. 2003;34:6-8.

12. Green S, Pichyangkul S, Vaughn DW, Kalayanarooj S, Nimmannitya S, Nisalak A, et al. Early CD69 expression on peripheral blood lymphocytes from children with dengue hemorrhagic fever. JID. 1999;180:1429-35.

13. Carlos CC, Oishi K, Cinco MT, Mapua CA, Inoue S, Cruz DJ, et al. Comparison of clinical features and hematologic abnormalities between dengue fever and dengue hemorrhagic fever among children in the Philippines. Am J Trop Med Hyg. 2005; 73:435-40.

14. Wells RA, Scout RM, Pavanand K, Sathitsathein V, Cheamudon US, Dermott M. Kinetics of peripheral blood leukocyte alterations in Thai children with dengue hemorrhagic fever. Infection and Immunity. 1980;28:428-33.

15. Ardianto B, Sumadiono, Sutaryo. Jumlah limfosit absolut dan relative pada infeksi dengue. Berkala Ilmu Kesehatan. 2002; 34:221-9.

16. Myint KS, Endy TP, Mongkolsirichaikul D, Manomuth C, Kalayanarooj S, Vaughn DW, et al. Cellular immune activation in children with acute dengue virus infections is modulated by apoptosis. JID. 2006;194: 600-7.

17. Juffrie M, Meer GM, Veerman AJ, Thijs LG, Hack CE. Inflammatory mediators in dengue virus infection: circulating interleukin-12 and interferon- $\gamma$. Dengue Bull. 2002;26:144-54. 